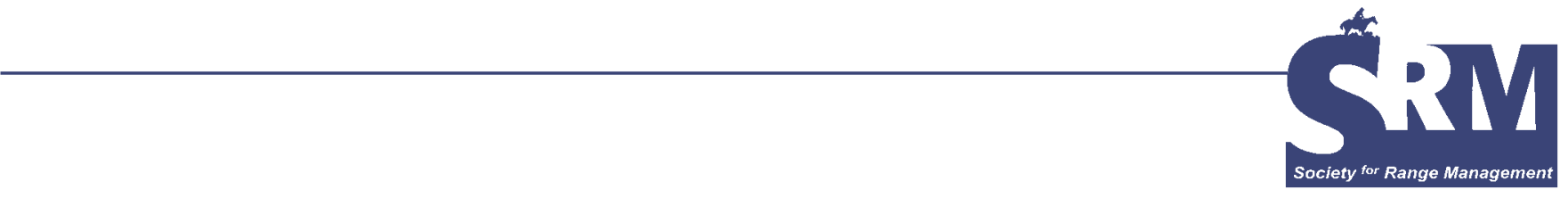

\title{
Accounting for the World's Rangelands
}

\section{By H. Gyde Lund}

$\mathrm{H}$ ow much rangeland do we have? Globally we do not know. I suspect the same can be said nationally. If we do not know what we have, how can we monitor it and develop a strategy for management? Existing statistics and definitions for rangelands or grasslands vary widely. In addition, definitions of various land classes such as rangeland and forest overlap. Not only is the definition important for accounting purposes, how one classifies lands could dictate who will administer the lands and how they will be managed.

To help resolve the problem, I offer a definition for rangelands that one can use to objectively inventory and report on rangelands at the national and international level. The intended audience is anyone who has to account for and report on the area of rangelands.

\section{Why Are Rangelands Important?}

Rangelands (including grasslands, shrublands, and tundra) are found throughout the world from the outback of Australia, to the muskegs and tundra of the Arctic, to the savannahs of Africa, to the cerrados of Brazil, to the plains of Mongolia, and to the sagebrush lands of the United States. As any range manager knows, rangelands are of key importance globally, nationally, and locally, both in terms of extent and socio-economic impact.

Properly managed rangelands can provide food security and poverty alleviation to millions of people. Rangelands are the main feed resource for traditional livestock rearing systems in many parts of the world. They provide about 70 percent of the feed for domestic ruminants. ${ }^{1}$ Rangelands are of great economic and social importance, because they offer a livelihood to millions of people. Traditional animal produc- tion provides people in developing countries with food (milk, meat, and blood), manure (for fuel and fertilizer), wool, hides, draft power, transportation, added security, and the possibility to accumulate capital. Livestock are also important in association with arable agriculture, because livestock provide the power for cultivation and manure for increased fertility. Livestock also consume crop residues, which often have no or little other value, except that straw can be used as roofing material or made into baskets. ${ }^{2}$

In addition, rangelands are vital for the ecological, environmental, and economic functions they provide. The multiple uses of rangelands, as with forests, are of great ecological significance because both vegetation types protect often-fragile soil profiles, store carbon, provide habitat for wild fauna and flora, and act as catchments or watersheds for large river systems.

Environmentally, rangelands provide biological diversity and ecological functions. They provide local, regional, and global values and regulatory and buffering services (for instance, corals reefs in the Caribbean are declining due to desertification in the Sahel; ${ }^{3}$ deforestation of the cerrados in Brazil affects the water balance in the whole of Amazon as well as the regional climate, etc.; all of these have major longterm impacts).

Economically, forests and rangelands provide us with essential goods and services. Both vegetation types contain medicinal plants, timber, germplasm for new and wild relatives of existing crop and pasture plants, and recreational opportunities. Furthermore, rangelands provide designated reserves. ${ }^{2}$

The economic importance of rangelands varies significantly according to the socio-economic system in which they are embedded. In developed economies, such as Australia and 


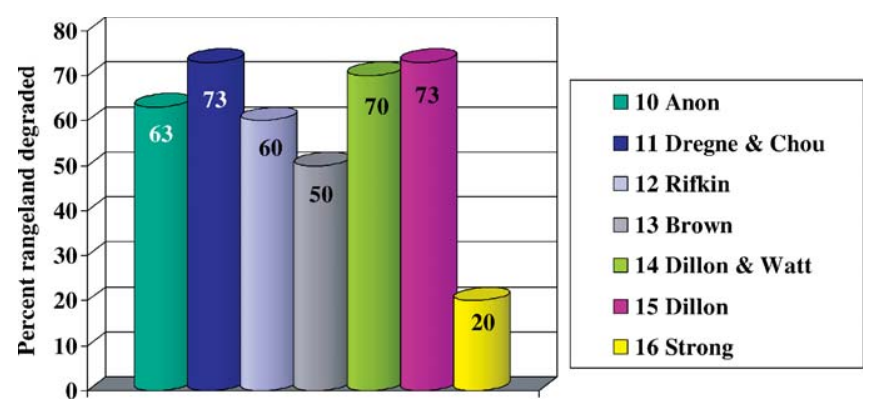

Figure 1. Recent estimates of percent of world's rangelands that are degraded.

the United States, rangelands are essentially marginal terrain suitable for low-intensity stock rearing and hunting, according to the Food and Agriculture Organization (FAO) of the United Nations. ${ }^{4}$ In pluralistic economies, such as Brazil, high-density vegetation such as rain forest, which is of crucial importance to hunter-gatherers and smallholder farmers, can all too easily be converted to low-fertility savannah, which is of interest to wealthy ranchers. In Africa and Central Asia, rangelands are essential to the subsistence of pastoralists, foragers, and farmers who are dependent on rainfed crops. ${ }^{4,5}$

\section{What Is Happening?}

Demographic pressures on rangelands are increasing. The demands put on rangelands by society are not limited to food and fiber. Rangeland management needs to meet multiple demands simultaneously, including outdoor recreation, hunting, water supply, and conservation. ${ }^{6}$

Threats to rangelands include climate change, overuse, and land conversion. Desertification is a global issue and can now be seen on every continent. ${ }^{7}$ However, perceptions of the condition of rangeland vary in accordance with the statistics used to evaluate it. Estimates of degraded rangeland vary from 680 million ha ${ }^{8}$ to 3.3 billion ha. ${ }^{9}$ The amount of the world's rangeland that one considers to be degraded ranges from $20 \%$ to $73 \%$ (Fig. 1).

\section{How Much Rangeland Is There?}

Rangelands are one of the Earth's major ecosystems. However, estimates of the amount of the Earth's land surface covered by rangelands vary from $18 \%$ to $80 \%$ (Fig. 2). The

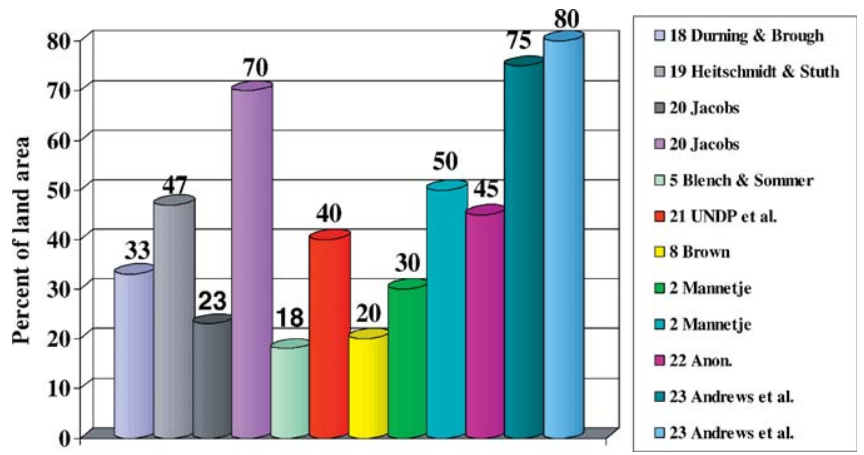

Figure 2. Recent estimates of world's rangeland (percent of total land area). ${ }^{17}$

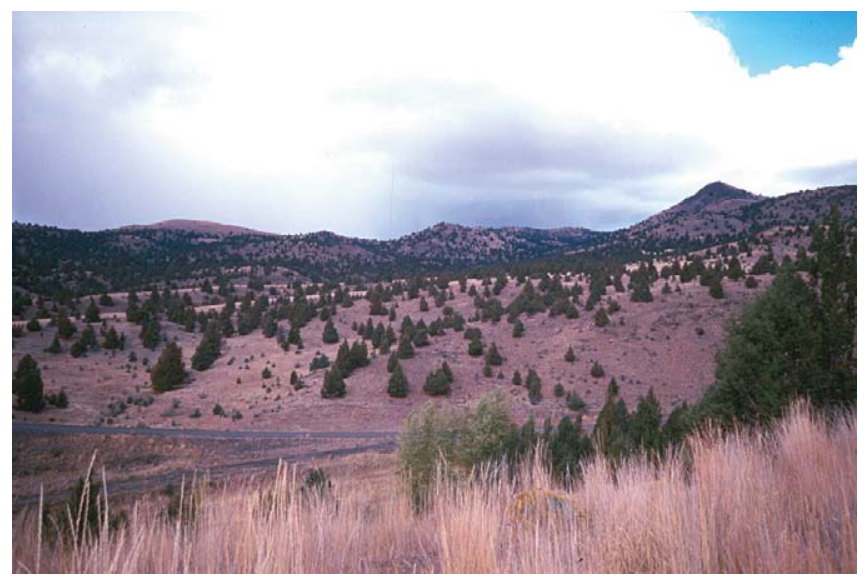

Figure 3. Juniper (Juniperus spp.) lands in central Oregon, United States. Is this forest or rangeland? Distinguishing between the two is important for determining land management objectives and avoids double counting of lands for national and international assessments.

variation is due to differences in bases (Earth surface, land surface, ice-free land surface, etc.), sources (ground surveys and inventories, remote sensing, climatic or soils maps, etc.), and the definitions used. The various percentages might be based upon the estimate of the Earth's total surface area, land area, or ice-free land area. Often authors do not provide a definition, state the foundation upon which they base the estimates, or give the source. Lastly, there is no international organization responsible for the assessment and reporting on the world's rangelands as there is for the periodic global forest assessments by FAO. As a result we really do not know how much rangeland we have at the global level.

If we wish to account for lands at the national and international level, definitions of various land classes should be mutually exclusive. Therefore to avoid double-counting, we should not consider the definition of "rangeland" without considering the definition of "forestland" because of potential for overlap (Fig. 3).

Figure 4 shows estimates of the world's forestland. Note there is less variation in estimate of land cover for the forest sector than there is for rangeland. The reason is simple-almost all the estimates come from FAO's Global Forest Resource Assessment (FRA). In turn, data from the FRA often come from national inventories of forestland harmonized to

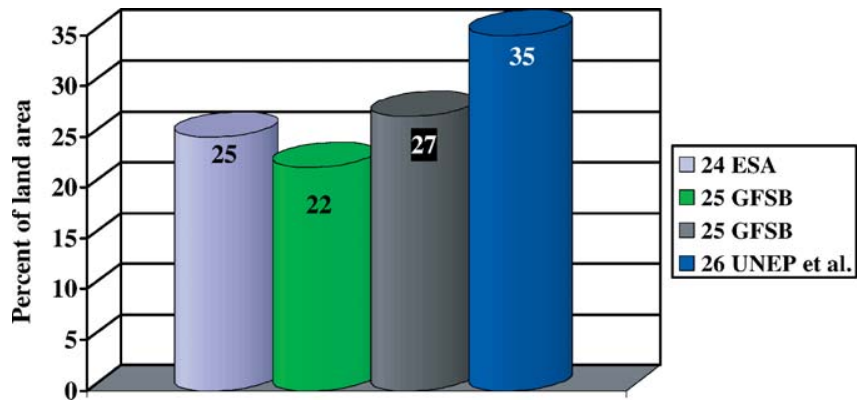

Figure 4. Recent estimates of the world's forestland (percent of total land area). ${ }^{17}$ 
Table 1. Example of different approaches for defining rangeland and forest

\begin{tabular}{|c|c|c|c|}
\hline Approach & Rangeland ${ }^{31}$ & Forest $^{32}$ & Comment \\
\hline Cover & $\begin{array}{l}\text { Lands dominated by } \\
\text { grasses and shrubs. }{ }^{33}\end{array}$ & $\begin{array}{l}\text { Land areas dominated by } \\
\text { trees where the tree cano- } \\
\text { py covers at least } 10 \% \text { of } \\
\text { the ground area. }{ }^{34}\end{array}$ & Easiest to use. \\
\hline Use & $\begin{array}{l}\text { Areas of land used exten- } \\
\text { sively by grazing animals. } \\
\text { Native grasses, shrubs and } \\
\text { woody vegetation generally } \\
\text { cover the area. }{ }^{35}\end{array}$ & $\begin{array}{l}\text { All land that is capable of } \\
\text { supporting a merchantable } \\
\text { stand of timber and is not } \\
\text { actively being used in a use } \\
\text { which is incompatible with } \\
\text { timber growing. }{ }^{36}\end{array}$ & $\begin{array}{l}\text { Difficult to separate what is } \\
\text { a forest use and what is a } \\
\text { rangeland use. }\end{array}$ \\
\hline Ecological or Potential & $\begin{array}{l}\text { A kind of land on which the } \\
\text { native vegetation, climax or } \\
\text { natural potential, consists } \\
\text { predominately of grasses, } \\
\text { grasslike plants, forbs, or } \\
\text { shrubs... }\end{array}$ & $\begin{array}{l}\text { Terrestrial ecosystem } \\
\text { (biome) with enough annual } \\
\text { precipitation (at least } 76 \\
\mathrm{~cm} \text { or } 30 \text { inches) to sup- } \\
\text { port growth of various spe- } \\
\text { cies of trees and smaller } \\
\text { forms of vegetation. }{ }^{24}\end{array}$ & $\begin{array}{l}\text { Taken literally, New York } \\
\text { City would qualify as forest } \\
\text { and Denver as rangeland. } \\
\text { The potential changes over } \\
\text { time. }\end{array}$ \\
\hline $\begin{array}{l}\text { Administrative or } \\
\text { gazetted }\end{array}$ & $\begin{array}{l}\text { Grassland: An administra- } \\
\text { tive unit of the USDA For- } \\
\text { est Service (more frequent- } \\
\text { ly "National Grassland"). }\end{array}$ & $\begin{array}{l}\text { An area within an adminis- } \\
\text { trative boundary of a forest } \\
\text { agency, whether having } \\
\text { trees or not. }{ }^{38}\end{array}$ & $\begin{array}{l}\text { Not all lands are classed } \\
\text { administratively. }\end{array}$ \\
\hline
\end{tabular}

FAO's definition of forestland, which is very objective and precise. ${ }^{27}$ The definition is as follows:

Forest includes natural forests and forest plantations. The term is used to refer to land with a tree canopy cover of more than 10 percent and area of more than $0.5 \mathrm{ha}$. Forests are determined both by the presence of trees and the absence of other predominant land uses. The trees should be able to reach a minimum height of $5 \mathrm{~m}$. Young stands that have not yet reached, but are expected to reach, a crown density of 10 percent and tree height of $5 \mathrm{~m}$ are included under forest, as are temporarily unstocked areas. The term includes forests used for purposes of production, protection, multiple use or conservation (i.e. forest in national parks, nature reserves and other protected areas), as well as forest stands on agricultural lands (e.g. windbreaks and shelterbelts of trees with a width of more than $20 \mathrm{~m}$ ) and rubberwood plantations and cork oak stands. The term specifically excludes stands of trees established primarily for agricultural production, for example fruit tree plantations. It also excludes trees planted in agroforestry systems. (p. 137).

Unfortunately there are no objective international definitions of rangeland. By objective I mean that if two or more different people visit a piece of land, they will all classify it the same. For example FAO defines rangeland as: "An area where wild and domestic animals graze or browse on uncultivated vegetation. ${ }^{28}$ Note there are no thresholds in this definition. What is the minimum area to be considered? How much vegetation, if any, has to be present? And so on. Without thresholds, classification of which lands qualify as rangelands will vary person to person.

Similarly, the United Nations Environment Programme ${ }^{9}$ defines rangeland as:
All territories presently used as grazing lands, which are accounted for in yearly FAOs statistics, as well as other non-agricultural, largely unoccupied, drylands which are used only occasionally by nomadic pastoralists or are presently unused at all.

As one can see, both definitions are vague. In addition, the facts that 1) there is no single organization that periodically accounts for the world's rangelands, and 2) very few nations have national rangeland inventory programs, leave any global estimates in question.

Because the area of rangeland is in question, any estimates of changes and conditions are also questionable. Holechek, ${ }^{29}$ for example, reports a loss of some 1.2 to 1.6 million ha per year of rangeland in the western United States and the Great Plains due to conversion to other uses. On the other hand, if one assumes that FAO's land use class of permanent pasture is equivalent to rangeland, then $\mathrm{FAO}^{30}$ reports an increase of the world's rangeland area from 3.1 billion ha in 1961 to nearly 3.5 billion ha in 2002. Despite the extent and importance of rangelands, most government and development agencies have neglected them.

How one classifies lands can affect how they are managed. For example, there is pressure throughout the world to maintain forestlands. If lands are classed as forest, environmentalists might wish to maintain tree cover. If lands are classed as rangeland, then tree cover may not be desirable and management strategies could be to eliminate the trees. Similarly, the classification of lands can affect which agencies are funded. For more forest, more money is required to protect or manage them. The same can be said about rangelands. In the United States alone, approximately 20 million ha of land 


\begin{tabular}{|l|l|l|}
\hline \multicolumn{2}{|c|}{$\begin{array}{l}\text { Table 2. Land uses (goods and services) provided } \\
\text { by rangelands and forests }\end{array}$} \\
\hline Goods and Services & Rangeland & $\begin{array}{l}\text { Forest- } \\
\text { lands }\end{array}$ \\
\hline Biological diversity & Yes & Yes \\
\hline Carbon sequestration & Yes & Yes \\
\hline Ecological functions & Yes & Yes \\
\hline $\begin{array}{l}\text { Environmental protec- } \\
\text { tion }\end{array}$ & Yes & Yes \\
\hline $\begin{array}{l}\text { Forage/crop produc- } \\
\text { tion }\end{array}$ & Yes & Sometimes \\
\hline Recreation & Yes & Yes \\
\hline Wood production & Sometimes & Yes \\
\hline Poverty alleviation & Yes & Yes \\
\hline
\end{tabular}

are in question as to whether they are rangeland or forest. ${ }^{17}$ This is why we need a workable definition of our land cover classes including rangelands.

\section{So Just What Should Be Considered "Rangeland?"}

Lund $^{31}$ lists over 300 published definitions of grassland, grazing land, pasture, shrubland, and rangeland. What one considers rangeland varies. To some, rangeland can be a type of land use, land cover, ecosystem, an administrative unit, or a combination of these categories. Table 1 compares different approaches for classifying rangeland and forest.

Rangeland is often defined as a land cover or land use. It is important to understand the differences between the two. Land cover is the vegetational and artificial constructions covering the land surface. ${ }^{39}$ It is the physical characteristic of earth's surface, captured in the distribution of vegetation, water, desert, ice, and other physical features of the land, including those created solely by human activities such as mine exposures and settlement. Land use, on the other hand, is the intent and management strategy placed on a land cover type. ${ }^{40}$ Forest, a land cover, can be used for selective logging, resource harvesting (such as rubber tapping), grazing, watershed protection, or recreation and tourism. Shifts in intent and/or management constitute land-use changes.

As stated above, when accounting for lands at the national or international levels, it is desirable that the land classes be mutually exclusive. When using land use as a classifier, the classes can overlap, as illustrated in Table 2.

To provide continuity in data collection and reporting, an objective and inventory-friendly definition should include thresholds for minimum area, percent vegetation cover, tree height (to separate rangeland from forestland), strip width, and listings of inclusions and exclusions such as is found in the FAO's definition of forest. Of the two types of defini- tions, it is easiest to develop an objective definition of rangeland based upon cover.

The following are some suggested guiding principles for developing an international classification system and definitions that would include rangelands for inventory and monitoring purposes. These are modified from the Vegetation Subcommittee ${ }^{41}$ of the US Federal Geographic Data Committee (FGDC) and the FGDC Earth Cover Working Group. ${ }^{42}$

- The definition(s) will build upon the existing work where possible.

- The definition(s) will use common terminology (i.e., terms should be understandable and jargon will be avoided).

- The definition(s) will be applicable over extensive areas and at a range of scales.

- Application of the definition(s) will be repeatable and consistent.

- Classifications should follow established scientific procedures where appropriate.

- The definition(s) will avoid developing conflicting concepts and methods through cooperative development with the widest possible range of individuals and institutions.

- The definition(s) will be mutually exclusive and additive to $100 \%$ of the Earth's land area, as represented on aerial photographs or satellite images.

- The definition(s) will be based upon existing, not potential, situations, and, in the case of vegetation cover, based upon condition at the optimal time during the growing season where such seasons exist.

- Land use classifications and nomenclature will be excluded from earth cover classifications and nomenclature.

\section{Hope at the International Level}

Two international activities could provide an objective structure for developing a definition. These include the Millennium Ecosystem Assessment (MA) and the Intergovernmental Panel on Climate Change (IPCC) Good Practice Guidance for Land Use, Land Use Change, and Forestry (GPGLULUCF).

The $\mathrm{MA}^{43}$ reports on finding for 10 categories of the land and marine surface, including forest, cultivated, dryland, coastal, marine, urban, polar, inland water, island, and mountain. Although rangelands are not discussed per se, dryland systems are defined as lands where plant production is limited by water availability; the dominant human uses are large mammal herbivory, including livestock grazing and cultivation. Drylands include cultivated lands, scrublands, shrublands, grasslands, savannas, semideserts, and true deserts. Dryland systems cover about $41 \%$ of Earth's land surface and are inhabited by more than 2 billion people.

The MA reporting categories are not spatially exclusive; their areas often overlap. For example, transition zones between forest and cultivated lands are included in both the forest system 
and cultivated system reporting categories. Thus there could be duplicate reporting in these categories. In addition, the MA synthesized existing information from the scientific literature, datasets, and scientific models, and included knowledge held by the private sector, practitioners, local communities, and indigenous peoples. There were no new data collected.

The IPCC has developed a classification scheme for reporting on greenhouse gas emissions that could provide estimates of rangelands at the national and international level using a common definition through the GPG-LULUCF. Of the 2 international activities, the IPCC represents the best construction for developing a definition.

To comply with the GPG-LULUCF, inventory agencies at the national level need information about land area for each of 6 classes to estimate carbon stocks and emissions, and removal of greenhouse gases associated with Land Use, Land-Use Change, and Forestry activities. The classes are "forestland," "cropland," "grassland," "wetland," "settlement," and "other land" for greenhouse gas inventory reporting. Milne and Pateh ${ }^{44}$ define these classes as follows:

Forestland-All land with woody vegetation consistent with thresholds used to define forestland in the national greenhouse gas inventory, sub-divided into managed and unmanaged, and also by ecosystem type as specified in the IPCC Guidelines 3. It also includes systems with vegetation that currently fall below, but are expected to exceed, the threshold of the forestland category. (p. 2.6)

Forestland is further defined by the Marrakesh Accords ${ }^{45}$ as follows:

"Forest" is a minimum area of land of 0.05-1.0 hectares (with tree crown cover or equivalent stocking level) of more than 10-30 per cent with trees with the potential to reach a minimum height of 2-5 metres at maturity in situ. A forest may consist either of closed forest formations where trees of various storeys and undergrowth cover a high portion of the ground or open forest. Young natural stands and all plantations which have yet to reach a crown density of 10-30 per cent or tree height of 2-5 metres are included under forest, as are areas normally forming part of the forest area which are temporarily unstocked as a result of human intervention such as harvesting or natural causes but which are expected to revert to forest. (p. 58).

Noteworthy about the Marrakesh forest definition is that there are no exclusions listed nor is there a minimum strip width threshold specified as often done in other definitions of "forest." ${ }^{46}$ However, Section 4.1.1 of the GPG-LULUFC, Step 1.1 specifies:

In addition to the minimum area of forest, it is good practice that countries specify the minimum width that they will apply to define forest unit and units of land subject to ARD [Afforestation, Reforestation and Deforestation] activities, as explained in Section 4.2.2.5.1. ${ }^{47}$

In addition, Milne and Pateh ${ }^{44}$ did not specify any minimum percent of cover for lands to be considered as vegetated. Given that the Marrakesh Accords has a minimum of 10-30 percent for forest, we can assume this threshold would apply to the other vegetation types.
- Cropland-Arable and tillage land, and agro-forestry systems where vegetation falls below the thresholds used for the forestland category, consistent with the selection of national definitions.

- Grassland-This category includes rangelands and pasture land that is not considered as cropland. It also includes systems with vegetation that fall below the threshold used in the forestland category and are not expected to exceed, without human intervention, the threshold used in the forestland category. The category also includes all grassland from wild lands to recreational areas as well as agricultural and silvipastural systems, subdivided into managed and unmanaged consistent with national definitions. [This would also include savannahs with tree cover less than the forest threshold.]

- Wetland-Land that is covered or saturated by water for all or part of the year (e.g., peatland) and that does not fall into the forestland, cropland, grassland or settlements categories. The category can be subdivided into managed and unmanaged according to national definitions. It includes reservoirs as a managed sub-division and natural rivers and lakes as unmanaged sub-divisions.

- Settlement-All developed land, including transportation infrastructure and human settlements of any size, unless they are already included under other categories. This should be consistent with the selection of national definitions.

- Other land-Bare soil, rock, ice, and all unmanaged land areas that do not fall into any of the other five categories. It allows the total of identified land areas to match the national area, where data are available. (p. 2.6).

The following is a proposed land classification key ${ }^{48}$ that incorporates the thresholds contained in the Marrakesh Accords and the IPCC classes. In this classification scheme "Rangeland" is synonymous with "Grassland" by default.

1 . Is the land area and strip width > national threshold? (Threshold must be between 0.05 and 1.0 ha.) Yes-Go to 2. No-Classify with surrounding area.

2. Is the land covered or saturated by water for all or part of the year? Yes = Wetland. No-Go to 3 .

3. Does the area have a vegetative cover (which can consist of woody, herbaceous, trees, shrubs, forbs, graminoids, mosses/lichen $s^{49}$ ) $>$ national threshold? (Threshold must be between $10 \%$ and 30\% during at least two months of the year.) Yes-Go to 4 . No-Go to 8 .

4. Does the land have tree crown cover $>$ national threshold (threshold must be between $10 \%$ and $30 \%$ ) or will it have such tree cover in the future? Yes-Go to 5. No-Go to 6 .

5. Do or will the trees reach the national threshold height (threshold must be between 2 and $5 \mathrm{~m}$ in height in situ at maturity)? Yes $=$ Forestland. No $=$ Non-forestland - Go to 6 .

6. Is the land used for growing crops? Yes = Cropland. No-Go to 7 .

7. Is the land dominated by grasses, forbs, or shrubs? Yes = Grassland (Rangeland). No-Go to 8 . 
8. Is the land developed for human activity? Yes = Settlement. No = Other land.

When applying the above categories, inventory agencies are to classify land under only one category to prevent double counting. Thus the classes are considered to be mutually exclusive and all-inclusive. Application could be particularly difficult because the IPCC classes are a combination of land cover and land use classes but it will be up to a nation to decide what goes where and when.

Based upon the above key, one could further refine a definition of grassland or rangeland for national and international accounting purposes as dry lands having at least ten percent vegetative cover at least two months of the year and less than ten percent tree cover and that are not used for growing crops. A workable definition of Rangelands definition based upon the IPCC categories is as follows:

Rangeland (including grasslands, shrublands, savannas, etc.): Any dry land at least_ ba in size and_ $m$ in width having at least_ percent vegetation cover at least_ months of the year and less than _percent tree cover and that are not used for growing crops. A tree is any woody perennial at least ${ }_{-} m$ tall.

The international community should determine the thresholds, or one might default to the thresholds already established that FAO uses for its periodic Global Forest Assessments: 0.5 ha for size, $20 \mathrm{~m}$ for width, and $10 \%$ cover of woody perennials at least $5 \mathrm{~m}$ tall. ${ }^{27}$ After plugging in the FAO thresholds, the definition becomes:

Rangeland (including grasslands, shrublands, savannas, etc.): Any dry land at least 0.5 ha in size and $20 \mathrm{~m}$ in width having at least 10 percent vegetation cover at least 2 months of the year ${ }^{49}$ and less than 10 percent tree cover ${ }^{27}$ and that is not used for growing crops. A tree is any woody perennial at least 5 $m$ tall.

A question arises if this level of specificity is needed. The answer is "Yes" if we ever hope to have reliable estimates of our land cover. Although this definition might not be acceptable by all, it does offer an opportunity for obtaining consistent and repeatable estimates of rangeland area at the national and international level.

\section{Conclusions}

Rangelands are important to us all for the goods and services they provide. Consequently, we need to be concerned about the extent and condition of these lands. However, there are no verifiable estimates of the world's rangeland areas. This is due in part to the lack of an objective definition of rangelands and the lack of national and international organizations that actually inventory and monitor rangelands. The definitional and accounting part could be solved by the recent issuance and national use of the Good Practice Guidance for Land Use, Land Use Change, and Forestry (GPG-LULUCF) from the IPCC. National implementation of the GPG-LULUCF should increase the local attention given to rangelandslitically, financially, and institutionally.

Additionally, on November 28, 2006, FAO announced that it is taking a new step forward and monitoring the management, uses, and users of all natural resources and their trends using an integrated approach. FAO is simultaneously monitoring all aspects of natural resources be it agriculture, forestry, fisheries, livestock, or wildlife, to build knowledge about the real environmental and socio-economic situations on the ground, making information closer to reality and relevant to policy makers. ${ }^{50}$

To obtain reliable estimates of rangeland and its changes, the various resource agencies and societies, especially the range management community, should promote an international definition followed by objective inventories. Without an objective definition and inventory, we will never know how much rangeland we have. If we don't know what we have, how can we adequately plan for and mange our rangeland resources?

It is hoped that this article will generate interest in the national and international accounting not only for rangelands but also for all lands. If all else fails, I encourage those who report area statistics to state both the definition they use and the source of their data.

\section{Acknowledgments}

My deepest thanks to Drs Paul Drichi, Coordinator, Inventory and Surveys, National Forestry Authority, Uganda; John A. Helms, Professor Emeritus, Dept of Ecosystem Science, University of California, United States; A. C. Grice, CSIRO Sustainable Ecosystems and R. B. D. Whaley, University of New England, Australia; and Len 't Mannetje, Agricultural University, Wageningen, The Netherlands; for their kind reviews and helpful comments on an earlier drafts of this article.

Author is Forestry Consultant, Forest Information Services, 6238 Settlers Trail Place, Gainesville, VA 20155-1374, gyde@ comcast.net.

\section{References}

1. Nicholson, R. A. 2000. Importance and areal extent of rangelands. Lecture Notes, Biological Sciences. Hays, KS: Fort Hays State University. Available at: http://www.fhsu.edu/biology/ ranpers/rm/importance.htm. Accessed 17 January 2006.

2. Mannetje, L. 2002. Global issues of rangeland management. 8 p. Available at: http://www.date/hu/acta-agraria/2002-08i/ mannetje.pdf. Accessed 24 September 2005.

3. Shinn, E. A., G. W. Smith, J. M. Prospero, P. Betzer, M. L. Hayes, V. Garrison, and R. T. Barber. 2000. African dust and the demise of Caribbean coral reefs. Geophysical Research Letters 271(9):3029-3032.

4. Food and Agriculture Organization. 2000. Pastoralism in the new millennium Rome, Italy: Food and Agriculture Organization of the United Nations. Animal Production and Health Paper 150.93 p.

5. Blench, R., And F. Sommer. 1999. Understanding rangeland biodiversity. Working Paper 121. London, United Kingdom: Overseas Development Institute. 51 p. 
6. Arnalds, O. 1999.Workshop report. Rangeland Desertification International Workshop. Iceland, September 16-19, 1997. Available at: http://www.rala.is/rade/workshop1997/conclusi. htm. Accessed 24 September 2005.

7. Bosch, O. J. H., W. J. Allen, J. M. Williams, and A. H. EnsoR. 1996. An integrated approach for maximising local and scientific knowledge for land management decision-making in the New Zealand high country. The Rangeland Journal 18(1):23-2.

8. BRown, L. R. 2002. World's rangelands deteriorating under mounting pressure. Earth Policy Institute Update 6: February 5, 2002-2. Available at: http://www.earth-policy.org/Updates/ Update6.htm. Accessed 12 May 2005.

9. United Nations Environment Programme. 1991. Status of desertification and implementation of the United Nations plan of action to combat desertification. Report of the Executive Director. Nairobi, Kenya: United Nations Environment Programme. Available at: http://www.na.unep.net/des/ uncedtoc.php3. Accessed 25 September 2005.

10. Anonymous. Undated. Genesis of Eden Diversity Encyclopedia. Available at: http://www.dhushara.com/book/diversit/ eye3.htm. Accessed 12 May 2005.

11. Dregne, H. E., And N-T. Chou. 1992. Global desertification dimensions and costs. In: H. E. Dregne, [ed.] Degradation and restoration of arid lands. Lubbock, TX: Texas Tech University. p. 249-281.

12. Rifkin, J. 1993. Cattle and the global environmental crisis. OPED 1. Beyond beef campaign. Available at: http://unreasonable. org/vegan/BeyondBeefRifkin.html. Accessed 12 May 2005.

13. Brown, L. 2001. What goes around....Why the world needs an eco-economy. The Ecologist. Available at: http://www. theecologist.org/archive_article.htm?article=261\&category=88. Accessed 12 May 2005.

14. Dillon, B., And P. Watt. 2003. The health of the Earth. Available at: http://www.callipygia600.com/callearth/indices. htm. Accessed 12 May 2005.

15. Dillon, J. 2003. The impact of the meat industry, grazing and factory farming on the environment. The Environmental Analysis Letter. City, State: Pomona College II(2).

16. Strong, R. 2004. Soil health based on organic matter. Available at: http://www.soilandhealth.org/01aglibrary/Richard\%20 Strong\%20Article.html. Accessed 30 November 2006.

17. Lund, H. G. 2004. Considerations for developing U.S. standard definitions of forest and rangeland. Report prepared for Meridian Institute, Contract No. 0045-A. Project No. 9147.8- Process to Develop a Definition of Forest and Rangeland. Gainesville, VA: Forest Information Services. 108 p. Revised 6 May 2005. Available at: http://fhm-server.lv-hrc. nevada.edu//fia/ab/issues/Final_report_F-R_7May05.doc. Accessed 12 May 2005.

18. Durning, A., And H. B. Brough. 1991. Taking stock: animal farming and the environment. World Watch Paper 103. Washington, DC: Worldwatch Institute. 62 p.

19. Неiтsснmidt, R., ANd J. Stuth [eds.] 1991. Grazing management: An ecological perspective. Portland, OR: Timber Press. 259 p.
20. Jacobs, L. 1992. Chapter 6 - Global Perspective. Waste of the West. Public lands Ranching. Tucson, AZ: Lynn Jacobs. 602 p.

21. United Nations Development Programme, United Nations Environment Programme, World Bank, World Resources Institute. 2001. World resources 2000-2001People and ecosystems: The fraying web of life. Washington, DC: United Nations Development Programme UNDP, the United Nations Environment Programme UNEP, the World Bank, and the World Resources Institute. Available at: http:// pdf.wri.org/wr2000_summary.pdf. Accessed 5 January 2007.

22. Anonymous. 2003. Grassland ecology and management. Lincoln, NE: University of Nebraska. Available at: http://snrs.unl. edu/degrees/undergrad_Rangeland_Ecosystems.asp. Accessed 30 November 2006.

23. Andrews, T., D. Hart, and J. Taylor. 2004. Challenges in participatory course design: the rangelands Australia experience. Presentation at the Effective Teaching and Learning Conference, Brisbane, Queensland, Australia: Griffith University, 4-5 November 2004. 9 p. Available at: http://www.rangelandsaustralia.com.au/publications/002_ChallengesinDesign_TA.pdf. Accessed 24 September 2005.

24. Environmental Protection Agency. 2000. Global warming glossary. Washington, DC: U.S. Environmental Protection Agency. Available at: http://yosemite.epa.gov/oar/ globalwarming.nsf/webprintview/Glossary.html. Accessed 25 September 2005.

25. Green Facts Scientific Board. 2003. How much forest is there in the world? Facts on Forests and Forestry. Available at: http://www.forestfacts.org/level_1.htm\#2. Accessed 5 January 2007.

26. United Nations Environment Programme and World Monitoring Conservation Center. 2003. Map and Statistics. Nairobi. Available at: http://www.unep-wcmc.org/forest/ world.htm. Accessed 5 January 2007.

27. Food and Agriculture Organization. 2001. State of the world's forests 2001. Rome, Italy: Food and Agriculture Organization of the United Nations. $181 \mathrm{p}$.

28. Harris, P. S. 2000. Grassland resource assessment for pastoral systems. FAO Plant Production and Protection Paper 162. Rome, Italy: Food and Agriculture Organization of the United Nations. Available at: http://www.fao.org/DOCREP/003/ X9137E/x9137e15.htm. Accessed 5 January 2007.

29. Holecheк, J. 2001. A growing population, rangelands \& the future. Rangelands 23(6):39-43.

30. Food and Agriculture Organization. 2004. FAOSTAT data, 2004. Rome, Italy: Food and Agriculture Organization of the United Nations.

31. Lund, H. G. 2006. Definitions of agroforestry, forest health, sustainable forest management, urban forests, grassland, pasture, rangeland, cropland, agricultural land, shrubland, and wetlands and related terms. Gainesville, VA: Forest Information Services. Misc. pagination. Available at: http://home. comcast.net/ gyde/moredef.htm. Accessed 17 January 2006.

32. Lund, H. G. 2006. Definitions of forest, deforestation, reforestation and afforestation. Gainesville, VA: Forest Information 
Services. Misc. pagination. Available at: http://home.comcast. net/ gyde/DEFpaper.htm. Accessed 17 January 2006.

33. Heinz Center. 2003. The state of the nation's ecosystems. Annual Update 2003. Available at: http://www.heinzctr.org/ ecosystems/grass/index.shtml. Accessed 24 September 2005.

34. Moyers, B. 2001. Glossary. Earth on the edge. PBS Broadcast. Available at: http://www.pbs.org/earthonedge/glossary.html. Accessed 25 September 2005.

35. Wilcocks, J., M. Howden, B. Sutherst, and B. Henry. 2003. Glossary. Climate changes. State of Queensland, Australia: Department of Natural Resources \& Mines. Available at: http://www.longpaddock.qld.gov.au/ClimateChanges/slides/ glossary.html. Accessed 24 September 2005.

36. Wнатсом County. Undated. Chapter 14.04 Right to practice forestry. Whatcom County Code. Washington: Whatcom County. Available at: http://www.mrsc.org/mc/whatcom/ whatco14whatco1404.html. Accessed 25 September 2005.

37. International Union of Conservation and Environment. Undated. Ecosystem Management. Fact Sheet. Available at: http://www.iucn.org/congress/documents/fact_ecosystem. htm. Accessed 12 May 2005.

38. Giles, R. H., JR. 1998. Glossary: Working words of wildland, natural resource, and land-use planning and management with select abbreviations Lasting Forests. Available at: http://fwie. fw.vt.edu/rhgiles/appendices/glossary.htm. Accessed $25 \mathrm{Sep}-$ tember 2005.

39. Burley, T. M. 1961. Land use or land utilization? Professional Geographer 13(6):18-20.

40. Turner, B. L. II, D. L. Skole, S. Sanderson, G. Fischer, L. Fresco, and R. Leemans. 1995. Land-use and land-cover change science/research plan. IGBP Report No. 35; IHDP Report No. 7. Stockholm, Sweden: International. 132 p.

41. Vegetation Subcommittee. 1997. Vegetation classification standard. Washington, DC: Federal Geographic Data Committee. 18 p. +3 appendices.

42. Earth Cover Working Group. 1998. Guiding principles. Washington, DC: Federal Geographic Data Committee. Available at: http://www.fgdc.gov/ecwg/gui_prin.html. Accessed 25 September 2005.

43. Millennium Ecosystem Assessment. 2005. Ecosystems and human well-being: synthesis. Washington, DC: Island Press, 137 p. Available at: http://www.millenniumassessment. org//en/Products.Synthesis.aspx. Accessed 18 September 2006.
44. Milne, R., and B. P. Pateh [co-ordinating lead authors]. 2003. Chapter 2: Basis for consistent representation of land areas. In: IPCC Good Practice Guidance for LULUCF. Kanagawa, Japan: Institute for Global Environmental Strategies, Intergovernmental Panel on Climate Change, National Greenhouse Gas Inventories Programme. 29 p. Available at: http://www.ipcc-nggip.iges.or.jp/public/gpglulucf/ gpglulucf_files/Chp2/Chpt_Land_Areas.pdf. Accessed 17 January 2006.

45. United Nations Framework Convention on Climate Change. 2002. Report of the Conference of the Parties on its seventh session, held at Marrakesh, Morocco, from 29 October to 10 November 2001. FCCC/CP/2001/13/Add.1. 69 p. Available at: http://unfccc.int/resource/docs/cop7/13a01.pdf. Accessed 5 January 2007.

46. Lund, H. G. 2002. When is a forest not a forest? Journal of Forestry 100(8):21-27.

47. Penman, J., M. Gytarsky, T. Hiraishi, T. Krug, D. Kruger, R. Pipatti, L. Buendia, K. Mina, T. Ngara, K. Tanabe, And F. Wagner. [EDs.] 2003. Definitions and methodological options to inventory emissions from direct human-induced degradation of forests and devegetation of other vegetation types. Intergovernmental Panel on Climate Change. IPCCXXI/Doc. 8. Kanagawa, Japan: IPCC Secretariat. 32 p.

48. Lund, H. G. 2006. Guide for classifying lands for greenhouse gas inventories. Journal of Forestry 104(4): 211-216. Available at: http://saf.publisher.ingentaconnect.com/content/saf/jof/ 2006/00000104/00000004/art00008. Accessed 5 January 2007.

49. Di Gregorio, A., And L. J. M. Jansen. 1996. FAO land cover classification: a dichotomous, modular-hierarchical approach. Paper presented at the US Federal Geographic Data Committee FGDC Vegetation Subcommittee and Earth Cover Working Group meeting. Washington, DC, 15-17 October 1996. Available at: http://www.fao.org/WAICENT/

FAOINFO/SUSTDEV/EIdirect/Eire0019.htm. Accessed 18 January 2006.

50. Food and Agriculture Organization. 2006. FAO takes a new integrated approach to information gathering on natural resources. Forestry News 2006. Rome, Italy: Food and Agriculture Organization of the United Nations. Available at: http://www.fao.org/forestry/newsroom/en/news/108780/ highlight_110469en.html. Accessed 5 January 2007. 